\title{
The Lived Experiences of Migrant Youths at Musina Town in the Limpopo Province of South Africa
}

\author{
Rapholo Selelo Frank
}

\author{
Department of Social Work, University of Limpopo, Private Bag X1106, 0721, Sovenga, South Africa
}

\begin{abstract}
This study sought to explore and describe the lived experiences of migrant youths in South Africa by using Musina as a case study. Several studies reveal that Southern Africa is faced with an increased number of international population movements. Upon their arrival in the host countries, immigrants encounter a vast number of challenges. The new economic theory of migration was used to pursue the aim of this study. This study was qualitative wherein case study and phenomenological designs were triangulated to purposively select 18 migrant youths in Musina. Data was collected through semi-structured interviews and was analysed thematically with the assistance of Nvivo software. Findings reveal that most migrant youths due to problems around documentation are being hated by local citizens and exploited by employers that they end up performing impractical jobs without any benefits and job security. Stigmatisation was also found to be a challenge that migrant youths deal with in South Africa. There should be stringent security at the Beit-Bridge border post to mitigate illegal cross-bordering to South Africa. Integrative programmes should be developed to accommodate legal immigrants into the welfare of South Africa. Immigration laws should have a clause on the monitoring of any job done by immigrants in the host countries. Further research is also recommended in other provinces of South Africa and with significant others such as local citizens and government officials.
\end{abstract}

Keywords: Lived Experience, Migrant Youth, Musina Town, South Africa.

\section{INTRODUCTION AND BACKGROUND}

Migration is an international issue that affects various disciplines to address it. It is estimated that about $3 \%$ (roughly 258 million) of people in the world have lived in a foreign country (United Nations [UN] 2017; International Organization for Migration [IOM] 2017). The rise of young people globally contributes towards a large number of migrant youths. There has been a rise in the number of youth migrants from 1990 to 2013 , with the number stemming from 23.2 million to 28.2 million (United Nations Children's Fund [UNICEF] 2014). Southern Africa encounters a vast number of international population movements (McDonald, 2000). This was also established from a study by IOM (2017) that South Africa has accommodated about four million migrants. In addition, the UN Department of Economic and Social Affairs [UNDESA] (2015) postulates that the percentages of international migrants in the Republic of South Africa have had the steepest increases in 2010 and 2017.

People, particularly, young people, migrate to foreign countries due to various reasons. According to the South African Department of Home Affairs [DHA] (2016) and Dubey and Mallah (2015), there has been a steady rise in migration due to several push and pull factors. Push factors include poverty, conflict, economic upheaval and environmental degradations

${ }^{*}$ Address correspondence to this author at the Department of Social Work, University of Limpopo, Private Bag X1106, 0721, Sovenga, South Africa; Tel: (+2715) 268 3876; E-mail: Frank.Rapholo@ul.ac.za
(Nicolai, Wales, and Aiazzi 2015). Furthermore, Nyasulu (2015) explains push factors as undesirable conditions in the home country that drive people out (e.g. violence, poverty, and/or unemployment). Violence is one of the major push factors in Africa. As a result, citizens flee to other countries for their safety. Push factors are adverse conditions that compel people to seek refuge in another country. Sipova, Ray, and Pugliese (2011) posit that push factors threaten the wellbeing, security, and livelihood of those experiencing them. Conversely, pull factors are favourable conditions that attract migrants to countries of destinations such as job opportunities, educational opportunities and better living standards (UN 2013) and speedy transport system, information communication technology (Dubey and Mallah, 2015). In addition, Kainth (2010) asserts that pull factors refer to desirable conditions that entice migrants to a particular area and that such conditions include, but are not limited to job opportunities, decent salaries, facilities, and decent working conditions. For example, compared to many on the African continent, the South African economy offers better job opportunities, higher wages, and business opportunities, hence, the country is one of the preferred destinations for foreign nationals. This is confirmed by South African History Online [SAHO] (nd) where it is indicated that the country of South Africa is Africa's most industrialised country and that it attracts thousands of foreign nationals every year, seeking refuge from poverty, economic crises, and war and government persecution in their home countries. SAHO also indicates that the majority of these foreign nationals are from elsewhere on the continent, such as 
Zimbabwe, Malawi, the Democratic Republic of Congo, Somalia, Ethiopia, and that many also come from Pakistan and Bangladesh.

Whilst people, in particular, young people migrate to foreign countries, they encounter various challenges and resort to various strategies to survive (UNDESA 2016). According to the Global Migration Group [GMG] (2013), young migrants are more vulnerable when, in combination with their age and stage of life, they experience isolation, exclusion, discrimination, and insecurity. Moreover, in the migration process young people can lose their social networks and may also be without parents or family members to provide guidance and care. This paper argues that there have not been ample studies in South Africa which rigorously explored the challenges experienced by migrant youth upon their arrival to the country yet the patterns and scale of these population movements are constantly in flux.

\section{Research Problem}

Southern Africa has a vast number of international migrant youths. Several studies show that many migrant youths, particularly those who come from African countries migrate to South Africa for better livelihoods and improved living conditions (Crush and McDonald 2002; Lee 2003; Thet 2014; Oyelana 2016 Rapholo, 2019). In addition, Rapholo (2020) purports that South Africa is a home for a vast number of migrant youths. Some of them are in Musina town, which is approximately $18 \mathrm{~km}$ away from the BeitBridge border post that divides South Africa and Zimbabwe where this study was conducted. Acknowledging that it is difficult to determine with precision the drivers of youth migration, it can be construed that young people's motivations are often linked to the search for sustainable livelihoods, due to lack of employment and/or under-employment, absence of decent working conditions, and poor economic prospects in countries of origin. While searching for sustainable livelihoods in South Africa, migrant youths face some challenges in the host foreign country. There have not been ample studies in Musina town which rigorously explored the lived experiences of migrant youths. Therefore, this study sought to explore and describe lived experiences of migrant youth in Musina town in the Limpopo Province of South Africa.

\section{Aim of the Study}

This study was aimed to explore and describe the lived experiences of migrant youths at Musina town in the Limpopo province of South Africa.

\section{Theoretical Framework}

This study was guided by the new economic theory of migration which was found by Stark in the 1980s. This theory arose in response to the neoclassical theory (Stark and Boom 1985). The neoclassical theory holds a perception that migration takes place because of wage differences between the receiving and sending countries. In other words, people migrate to earn more wages in the host countries which their home countries fail to provide. Then the new economic theory was developed with the perception that a wage differential is not a necessary condition for deciding between migration to another country, but families, households and other culturally defined units of production and consumption are those who count and not an individual. This theory argues that migration is not determined by an individual migrant independently, but a mutual interdependence (Stark 1991; Kurekova 2011; Wickramasinghe and Wimalaratana 2016). This theory was useful in this study to help the researcher to understand those migrant youths came into South Africa not to only seek better living standards but also to their families who they have left in their home countries. The new economic theory of migration views migration as a household decision to avoid the risks of family income. Young people migrate due to a set of factors (such as socio-economic turmoil) that are shaped by conditions in their home countries. In the context of this study, youths migrated to South Africa due to poor conditions in their home countries (specifically, from their families) with the hope for the better so that they can improve those of their families. Whilst writing this paper, the researcher has put into cognisant those factors.

\section{METHODOLOGY}

A qualitative approach with a descriptive case study and phenomenological designs were used to pursue the aim of this study. A qualitative approach were used as this research sought to gain the understanding, knowledge, and insight of migrant youths regarding their lived experiences in South Africa. This approach was useful as it enabled the researcher to gain firsthand experience from the participants (Creswell 2003). Using a descriptive case-study design, Musina town served as a case study. Fouché and Schurink (2011) denote that researchers who opt for descriptive case studies use a small number of instances to produce a detailed description of cases. Eighteen migrant youths who are accommodated in churches at Musina- town were purposively selected for this study. Out of these 
migrant youths, eight (8) were female and ten (10) were male. To understand the phenomena under the investigation on participants' terms who also described their human experiences (Fouché and Schurink 2011) the researcher followed a phenomenological research design. Semi-structured interviews and observations were used to collect data that were analysed thematically through the help of the Nvivo Software. To ensure the quality of the findings, credibility, conformability, transferability, and dependability were followed. Credibility through prolonged engagement, member checking, and peer examination was ensured, and field notes were written directly after each interview with each participant for auditing purposes to endure the conformability of the findings. Data were correctly coded for dependability purposes This study obtained ethical clearance from the Turfloop Research Ethics Committee (TREC) of the University of Limpopo with a project number TREC/74/2019: IR. Furthermore, permission to conduct research was granted by Musina Local Municipality in the Limpopo Province of South Africa and churches that manage shelters for refugees.

\section{FINDINGS AND DISCUSSION}

The following themes emerged upon the interviews with migrant youths in Musina town about their lived experiences.

\section{Theme 1: Hatred by Local Citizens}

A large number of migrant youths lamented about hatred by local citizens as one of the problems they encounter in South Africa. The other participant indicated that some local citizens are of the view that they take away their job opportunities whilst some stated that they are perceived as criminals. These were attributed to hatred amongst the local citizens for foreign nationals. Findings support previous studies in that most xenophobic attacks today emanates from job competitions and crime because many people are competing for scarce resources (Nyamnjoh 2006; Crush 2008; Crush and Ramachandran 2011; Averatt 2011; Daily Dispatch 2015; United Nations Higher Commission for Refugees [UNHCR] (2017). This was a response from one migrant youth from Angola:

"They hate us. Some don't even pretend to love us. You look at their faces, you just see hatred. lyoooo!! To be a foreign national in South Africa is like a curse. One South African even told me that we take away their job opportunities."
In the same breath, the other participant from Zimbabwe echoed that:

"I was once innocently beaten up for nothing because every crime committed in the area is associated with us. To be honest, I do not know about that crime, but South Africans made false allegations that it was committed by myself. That is hatred I am telling you. Our Government back from my country pushed us to slavery because what pushed us here is hunger".

These findings correlate with previous studies in that since 1994, there were xenophobic practices and violence against foreign nationals in some provinces of South Africa, such as Gauteng, Western Cape, Free State, Limpopo, and KwaZulu Natal have worsened (South African History Online [SAHO] nd). Xenophobia is a strong dislike, hatred, or fear of foreigners and strangers (UNHCR 2017). As a result of hatred, foreign nationals (migrant youth in the context of this study) are victimised by the local citizens of South Africa. The other participant stated that the local citizens due to how they hate them, built on negative stereotypes, attitudes, or perceptions and that sometimes that leads to intolerance, violence, human rights abuse, or even death towards foreigners in extreme cases. This is what the other migrant youth from Malawi stated:

"Some South Africans cannot tolerate us. They hate us that they even have negative perceptions and attitudes about us. We have incidents where some of the immigrants were found killed and that scare us. We are at risk in this country".

It can thus be deduced from these findings that there is still a lack of oneness amongst Africans. This was also stated by Adjai and Lazaridis (2013) who established in their study on migration that xenophobia and a new wave of racism is rampant in post-apartheid South Africa, and that most South African citizen's actions today are not aligned with the Constitution of the Republic of South Africa, which embodies a culture of inclusiveness, tolerance and human rights, which was the case in the early years of the post-apartheid era. South Africans tend to blame black foreigners from other African countries for the socio-economic problems of their country. The majority of South African citizens, as a result, perceive the presence of immigrants as a threat to jobs, food, education, and other amenities provided by the government. As such, 
immigrants become more vulnerable to attacks. The South African government policies on refugee protection are been violated. Xenophobia poses a serious threat to refugee protection and democracy in South Africa by negating the principles of human rights. Some migrant youths indicated that due to the level of hatred by the local citizens, they are subjected to discrimination, particularly during the governmental service provisions as they are portrayed as a burden and parasitical to the state. This supports what the other pastor from Rapholo's (2020)' study indicated in that access to government services amongst immigrants is a serious challenge in South Africa. This is what the other migrant youth from Zimbabwe stated:

"Seemingly we Zimbabweans are a lot here in South Africa. The way we are being hated, government officials do not want to even see us. We starve and suffer because of our nationality".

Xenophobia resulting from hatred by local citizens affects the rights of immigrants in South Africa in various forms and has negative impacts on their ability to have access to services in both private and public fora. This is supported by Timngum (2001) by stating that xenophobic attacks and intimidation against immigrants in South Africa suggest that there may be systematic intolerance and violation of human rights of non-nationals which may affect their access to services, jobs, housing, and other aspects of their daily lives. It is therefore imperative that South Africans accommodate other citizens from the neighbouring African countries in their space(s).

\section{Theme 2: Exploitation by Local Employers}

It was also established that some migrant youths are exploited by their employers. The majority of migrant youth in South Africa are exposed to poor working conditions by performing impractical jobs without any benefits and job security. This is what the other migrant youth from Malawi stated:

"You know what, the kind of jobs we do, you will not like them. What we need is to only address hunger. We are without a home and relatives here. So if anyone comes by the church looking for workers, we run to them at a large number regardless of how much we are going to be compensated. After we have done the job, the employer never cares about us.
We come back to the church and search for other jobs.

In the same wavelength, the other migrant youth from DRC stated that:

"Sometimes our employers do not give us money but clothes. There is nothing we can do. Some of us do not have legal documents and they can't give us permanent jobs. So we just work for them regardless of the kind of a job we do because we shall die of hunger".

It can be deduced from these findings that starvation amongst migrant youth in South Africa and the lack of legal documents expose them to exploitation by local employers. It is unfortunate that for one to access government services, they should produce identification documents which is not the case with the migrant youth who participated in this study as most are without such documentaries. Findings support previous studies which found that immigrants are exposed to horrible working conditions and are underpaid (Drinkwater et al. 2006; Dumba and Chirisa 2010; Sumption and Somerville 2009; Netto et al. 2011; Rienzo 2013; Serumaga-zake 2017). It can be strongly be deduced that local employers employ most immigrants as they are aware that they have no higher expectations. The researcher argues that migrant youth are provided with cheap labour. This argument is confirmed by several scholars who researched in South Africa that employers find it cheaper to employ migrant youth as they are prepared to work long hours, have lower salary demands and are likely to work under any conditions, and are willing to take jobs rejected by local workers (Anderson and Ruhs 2012; Dench et al. 2006; Datta et al. 2007; Maharaj and Moodley 2013).

The other migrant youth who has legal documents stated that she has handed over her identifying documents to the employer because she does not want to lose her job even though she does not get enough wage and that her employer does not give her day-offs. This correlates with Pemberton et al. (2014) and Poinasamy (2011) who state that migrants are expected to perform impractical tasks; they would be on duty every day without days off, would not be provided with their private space, and would also surrender their passports and identity documents to the employer in so doing they diminish the prospects of securing employment elsewhere. This is what the migrant youth stated: 
"I had to hand over my identification documents to my employer because I wouldn't want to lose the job even though he pays me peanuts, but it's better than nothing".

While migrants leave their home countries due to barren employment opportunities for better ones elsewhere, the above paints a bleak picture in terms of depiction of migrants' exacerbated suffering in countries of destination. Some migrant youths have indicated that their employers did not register them anywhere to benefit in case they lose their jobs. This is what the other migrant youth stated:

"You know what, I am very loyal to my employer and doing a very good job but I am not even registered to the UIF since I have legal documents. This means that should he decide to chase me away I have lost'.

These findings show that migrant youths are "willing workers" who always do a satisfactory piece of work resulting in increased production without being registered for the provision of benefits to immigrants. As a consequence, they are employed on a casual or daily basis and become vulnerable to retrenchment whenever business is poor. Migrants do the piece jobs without belonging to any union and they get fired after the employers have satisfied their requirements. If migrant youth does not belong to unions, resulting in exploitation levels being high and, local unions are hostile to the migrants who are seen to be taking the jobs of South Africans. The researcher believes that this makes it easy for their employers to fire or retrench them from work whenever they want or when they feel they no longer need their services. Migrant workers are willing to be exposed to precarious working conditions in exchange for higher salaries than those in their home countries (Equality and Human Rights Commission [EHRC] 2010; Anderson and Ruhs 2012). They assent to diabolical working conditions with the view that it is temporal.

\section{Theme 3: Stigmatisation}

Stigma also emerged during the interviews with migrant youths where it was indicated that they have been given names that differentiate them from the local citizens, i.e "Amakwerekwere", a derogatory word that refers specifically to unintelligible sounds of a foreign language. This labelling according to (Hickel 2014) portrays the image of the foreign migrant as being the
"Other". Foreign migrants are viewed in stark difference to local South Africans. The other migrant youth from Angola stated that being considered as the "other or lekwerekwere", it becomes easy to apportion blame for shortcomings and other misfortunes that may arise within the community. This is what the migrant youth echoed:

"We are not regarded as any local person within the communities. They have given us a name; amakwerekwere. This name makes us seem different from the local citizens and should anything bad happen within the community, that is more likely to be associated with us."

In support of these findings, Murray (2003) and Dodson and Oelofse (2000) contends that the influx of illegal aliens is usually perceived to be responsible for any negative incidents within the host countries such as importing diseases, depressing wages, consuming social services, and exacerbating unemployment, destroying local parks and recreational facilities and transforming the inner city neighbourhoods into squalid slums. Immigrants are deemed as cases of discord in their host countries. As a result, they encounter violence from the citizens of their host countries. The stigma attached to migrant youths is perceived by Daily Dispatch (2015) to be determined by two variables, namely; Black African immigrants and European Immigrants. In South Africa, it is indicated that the negative attitudes of the South Africans towards European immigrants are few. This might be as a result of the perception that black people from other African countries are poor and are seen migrating to South Africa for job opportunities. According to Crush (2008) and Daily Dispatch (2015), South Africa is one of the places where other black foreigners are treated worse than migrants from North America and Europe. This shows that immigrants from other African countries are more vulnerable in South Africa than from the rest of the world.

\section{CONCLUSION}

Immigration, particularly the migration of youths is a global problem that requires academics, practitioners, and communities to collaborate their efforts in addressing this socio-economic-political phenomenon. It can be noted from this paper that immigrants, particularly young migrants encounter a vast number of challenges upon their entry into the host countries. More research from other regions of South Africa is needed so as develop proper integrative programs that 
will advocate for the needs of immigrants. Findings revealed that the challenges that young migrants in Musina town face start with their lack of legal documents, which in turn prevents their integration into the welfare system of South Africa. Therefore, to curb this problem, all stakeholders not only in Musina town but also in the entire country should coordinate their services according to the specifications in the immigration laws. Immigration laws in the host and home countries should be reviewed and tightened, especially about crossing the border without legal documents. This could be the reason why government service providers are reluctant to provide service to immigrants. The security at the border should also be tightened to ward off refugees who cross the border without permits, probably by installing surveillance cameras at the border. This will minimise the number of young migrants who are illegally in foreign countries. The government of South Africa together with the government of Zimbabwe should work together towards addressing the migration of young people at the Beit-Bridge border post. With regards to the exploitation of migrant youth by local employers, stringent measures or policies which should as well be flagged in the immigration laws should be developed and kept to monitor every job done by immigrants whilst in a host country. Lastly, findings have shown that the local citizens of South Africa hate, reject, and hold a negative stigma against migrant youths. As such, the researcher recommends a culture of accepting each other as Africans amongst the South African citizens. Further research should be conducted to get data from the perspectives of the significant others such as local citizens and government officials to the migration of young people to Musina town in South Africa.

\section{FUNDING AND ACKNOWLEDGEMENT}

This study was funded by the National Research Foundation in South Africa with a Grant No: 116810.

\section{COMPETING INTERESTS}

The author declares that there is no competing conflict of interest in this paper.

\section{AUTHORS' CONTRIBUTIONS}

I declare that I am the sole author of this paper.

\section{REFERENCES}

Anderson, B. and Ruhs, M. 2012. 'Reliance on migrant labour: inevitability or policy choice?' Journal of Poverty and Social Justice, 20(1): 23-30.

https://doi.org/10.1332/175982712X626743
Bollini, P. and Siem, H. 1995. No real progress towards equity: Health of migrants and ethnic minorities on the eve of the year 2000. Social Science and Medicine, 41(6), 819-828. https://doi.org/10.1016/0277-9536(94)00386-8

Carrasco, L. N. 2016. End-of-life care and death of migrants. In Handbook of Migration and Health. Edward Elgar Publishing.

Castles, S. and Miller, M. J. 2009. Migration in the Asia-Pacific region. Migration Information Source, 10.

Commission of the European Communities. 2008. Report on Quality and Equality of Access to healthcare services. Retrieved from http://www.euro.centre.org/data.

Crul, M. 2007. The integration of immigrant youth: Learning in the global era. International perspectives on globalization and education, 213-231. https://doi.org/10.1016/0277-9536(94)00386-8

Crush, J. and Tawodzera, G. 2011. Medical Xenophobia: Zimbabwean access to health services in South Africa. Cape Town. SAMP.

Crush, J. 2008. The Perfect Storm: The Realities of Xenophobia in Contemporary South Africa. Cape Town: Idasa.

Crush, J. 2011. Complex Movements, Confused Responses: Labour Migration in South Africa. Cape Town: SAMP. (SAMP Policy Brief, 25)

Daily Dispatch.2015. Generally stinking attitudes towards foreign Africans. http://wwwdispatch live .co.za/opinion/generally-stinking-attitudetowards-foreign-african/. (Retrieved January 21, 2016).

Datta, K., Mcllwaine, C., Wills, J., Evans, Y., Herbert, J., and May, J. 2007. 'The new development finance or exploiting migrant labour: remittance sending among low-paid workers in London'. International Development Planning Review, 29(1): 43-67. https://doi.org/10.3828/idpr.29.1.3

Dench, S., Hurstfield, J., Hill, D., and Akroyd K. 2006. Employers' Use of Migrant Labour. 04/06. London: Home Office.

Department of Home Affairs. 2016. Towards a white paper on international migration in South Africa. Pretoria: Government printers.

Dodson, B. and Oelofse, C. 2000. Shades of Xenophobia: In-Migrants and Immigrants in Mizamoyethu, Cape Town.Canadian Journal of African Studies / Revue Canadienne des ÉtudesAfricaines. Special Issue: Transnationalism, African Immigration and New Migrant Spaces in South Africa. 4(1):124-148. https://doi.org/10.1080/00083968.2000.10751188

Drinkwater, S., Eade, J. and Garapich, M. 2006. 'Poles apart? EU enlargement and the labour market outcomes of immigrants in the UK'. IZA Discussion Paper No. 2410, October. London: IZA.

Dubey, S \& Mallah, V. 2015. Migration: causes and effects. The Business \& Management Review, Volume 5 Number 4

Dumba, $S$ and Chirisa, I. 2010. The plight of illegal migrants in South Africa: A case study of Zimbabweans in Soshanguve extension 4 and 5. International journal of politics and good governance.

Equality and Human Rights Commission. 2010. Inquiry into Recruitment and Employment in the Meat and Poultry Processing Sector. Report of the Findings and Recommendations. London: EHRC.

Everatt, D. 2011. Xenophobia, state and society in South Africa, 20082010. Politikon, 38(1), 7-36. https://doi.org/10.1080/02589346.2011.548662

Flatau, P., Smith, J., Carson, G., Miller, J., Burvill, A., and Brand, R. 2015 The housing and homelessness journeys of refugees in Australia. Melbourne: Australian Housing and Urban Research Institute.

Global Migration Group. 2013. Integrating migration in the post-2015 UN Development Agenda: Position Paper. Global Migration Group. September 2013.

Greenburg, J. and Polzer, T. 2008. Migrant Access to Housing in South African Cities. Migrants' Rights Monitoring Project. Johannesburg. Witwatersrand University. (Forced Migration Studies Programme special report no 2).

Hacker, N. F., Gambone, J. C., and Hobel, C. J. 2015 . Hacker \& Moore's essentials of obstetrics and gynecology. Elsevier Health Sciences.

Hickel, J. 2014. "Xenophobia" in South Africa: Order, Chaos and the Moral Economy of Witchcraft. Cultural Anthropology, 29(1):103127.

https://doi.org/10.14506/ca29.1.07 
International Labour Organisation. 2013. Global employment trends for youth report. Retrieved from https:// ilo.org/global/publications

International Organization for Migration. 2017. World migration report 2018. Switzerland: International Organization for Migration.

Kainth, G.S. 2010. Push and Pull Factors of Migration: A Case Study of Brick Kiln Migrant Workers in Punjab. Retrieved from https://mpra.ub.uni-muenchen.de/30036/.on

Kurekova, L. 2011. "Theories of migration: Conceptual review and empirical testing in the context of the EU East-West flows". In Interdisciplinary conference on Migration. Economic Change, Social Challenge (pp. 901-918).

Maharaj B. and Moodley, V. 2013. New African Immigration to the Durban Region. Canadian Journal of African Studies, 34(1):149-160. https://doi.org/10.1080/00083968.2000.10751189

Massey, D. S., Arango, J., Hugo, G., Kouaouci, A., Pellegrino, A., and Taylor, J. E. 1993. Theories of international migration: A review and appraisal. Population and development review, 19(3), 431466. https://doi.org/10.2307/2938462

May, J., Wills, J., Datta, K., and Evans, Y. 2006. The British State and London's Migrant Division of Labour. London Queen Mary, University of London.

McDonald, D. A. 2000. On borders: Perspectives on international migration in Southern Africa. Cape Town: Macmillan.

Mchunu, S. I. 2015. Migration and health: exploring the experiences of African immigrant car guards in Durban, Kwazulu-Natal. (Doctoral dissertation).

Murray, M. J. 2003. Alien Strangers in Our Midst: The Dreaded Foreign Invasion and "Fortress South Africa" Canadian Journal of African Studies / Revue Canadienne des Études Africaines, 37(2/3):440466. https://doi.org/10.1080/00083968.2003.10751275

Netto, G., Sosenko, F., and Bramley, G. 2011. A Review of Poverty and Ethnicity in Scotland. York: Joseph Rowntree Foundation.

Nicolai, S., Wales, J., \& Aiazzi, E. 2016. Education, migration and the 2030 Agenda for Sustainable Development.

Nkosi, N.G. 2004. Influences of xenophobia on accessing health care for refugees and asylum seekers in Johannesburg. (Doctoral dissertation).

Nyamnjoh, F. B. 2006. Insiders and outsiders: Citizenship and xenophobia in contemporary Southern Africa. Zed Books. https://doi.org/10.5040/9781350220775

Nyasulu, D.T. 2015. 'Pull' Factors of International Migration to South Africa. Retrieved from http://sihma.org.za/wpcontent/uploads/2015/03/2

Pemberton, S., Phillimore, J., and Robinson, D. 2014 .Causes and experiences of poverty among economic migrants in the UK, IRIS Working Paper Series, NO. 4/2014

Poinasamy, K. 2011. 'Protecting migrant domestic workers in the UK'. Gender and Development, 19(1): 95-104. https://doi.org/10.1080/13552074.2011.554027

Polzer, T. 2008. Responding to Zimbabwean migration in South Africa: evaluating options. South African Journal of International Affairs, 15(1):1-28.

https://doi.org/10.1080/10220460802217926
Pursell, I. 2005. Access to Health Care among Somali forced migrants in Johannesburg. (Doctoral dissertation).

Rapholo, S. F. (2020). Perceptions of church leaders on the integration of migrant youth into South Africa: The case of refugees in the refugee camps managed by churches at Musina. Theologia Viatorum, 44(1), 6.

Rienzo, C. 2013. Characteristics and Outcomes of Migrants in the UK Labour Market. Oxford: Migration Observatory.

Ruhs, M. 2006. 'The potential of temporary migration programmes in future international migration policy', International Labour Review, 145(1-2). https://doi.org/10.1111/j.1564-913X.2006.tb00008.x

Serumaga-Zake, A.E. 2017.Migration and Tourism: The Challenges of Zimbabwean Diaspora in South Africa. African Journal of Hospitality, Tourism and Leisure, Volume 6 (4)

Sipova, N., Ray,J and Pugliese, A. 2011. Gallup World Poll: The Many Faces of Global Migration. International Organisation for Migration Research Series, No. 43. https://doi.org/10.18356/88e934ea-en

Spencer, S., Ruhs, M. anderson, B., and Rogaly, B. 2007. The Experiences of Central and Eastern European Migrants in the UK. York: Joseph Rowntree Foundation.

Stark, O. 1991. The migration of labor. Cambridge: Basil Blackwell.

Stone, L. and Winterstein, S. 2003. A Right Or a Privilege?: Access to Basic Education for Refugee and Asylum-seeker Children in South Africa. National Consortium for Refugee Affairs.

Sumption, M. and Somerville, W. 2009. The UK's New Europeans London: Equality and Human Rights Commission.

Timngum, D. 2001. Assisting urban refugee children in South Africa: humanitarian challenges to state and non-state actors. MA. Socthesis. University of the Witwatersrand, Johannesburg.

Tomanek, A. 2011. Understanding migration: International migration theories.

United Nations Children's Fund. 2014. Migration and youth: Challenges and opportunities. United States of America: New York

United Nations Department of Economic and Social Affairs. 2015. International Migration Report. New York. United Nations

United Nations Higher Commission for Refugees. 2017. The Refugee Convention. [Online] UNHCR. Available at http://www.unhcr.org/1951-refugee-convention.html on 26th April, 2017 UNHCR., 2008. Global Report for 2007. UNHCR. Geneva: 249-253.

United Nations. 2017. International Migration Report 2017.United States of America: New York

Vearey, J., Richter, M., Núñez, L., and Moyo, K. 2011. South African HIVIAIDS programming overlooks migration, urban livelihoods, and informal workplaces. African Journal of AIDS Research, 10(sup1), 381-391. https://doi.org/10.2989/16085906.2011.637741

Wickramasinghe, A. A. I. N. and Wimalaratana, W. 2016. International migration and migration theories. Social Affairs: A Journal of Social Sciences, 1(5), 13-32.

\section{https://doi.org/10.6000/1929-4409.2021.10.186}

(C) 2021 Rapholo Selelo Frank; Licensee Lifescience Global.

This is an open access article licensed under the terms of the Creative Commons Attribution License (http://creativecommons.org/licenses/by/4.0/) which permits unrestricted use, distribution and reproduction in any medium, provided the work is properly cited. 